\title{
Effect of temperature on the degradation of bioactive compounds of Pinot Noir grape pomace during drying
}

\author{
Efeito da temperatura na degradação de compostos bioativos do bagaço de uva \\ Pinot Noir durante a secagem
}

\begin{abstract}
Aline Soares Cascaes Teles ${ }^{1 *}$, Davy William Hidalgo Chávez ${ }^{1}$, Flávia dos Santos Gomes², Lourdes Maria Corrêa Cabral ${ }^{2}$, Renata Valeriano Tonon ${ }^{2}$

1 Universidade Federal Rural do Rio de Janeiro (UFRRJ), Departamento de Tecnologia de Alimentos (DTA), Seropédica/RJ - Brazil

2 Embrapa Agroindústria de Alimentos, Rio de Janeiro/RJ - Brazil
\end{abstract}

\section{*Corresponding Author}

Aline Soares Cascaes Teles, Universidade Federal Rural do Rio de Janeiro (UFRRJ), Departamento de Tecnologia de Alimentos (DTA), Rodovia BR 465, km 07, s/n, Zona Rural, CEP: 23890-000, Seropédica/RJ - Brazil, e-mail: aline_cascaes@yahoo.com.br

Cite as: Effect of temperature on the degradation of bioactive compounds of Pinot Noir grape pomace during drying. Braz. J. Food Technol., v. 21, e2017059, 2018

Received: Apr. 30, 2017; Accepted: July 12, 2017

\section{Abstract}

The objective of this study was to evaluate the effect of temperature and drying time on the total phenolic content and antioxidant capacity of grape pomace. Experimental data of the drying kinetics were fitted to six mathematical models and the Page model was selected as the most suitable to represent the drying of grape pomace. The best preservation of the phenolic compounds and antioxidant capacity was observed at $60^{\circ} \mathrm{C}$, suggesting that the temperatures of $40^{\circ} \mathrm{C}$ and $50{ }^{\circ} \mathrm{C}$ were not sufficient to inactivate the enzyme polyphenol oxidase, being responsible for the greater degradation of these compounds.

Keywords: Antioxidant capacity; Drying kinetics; Mathematical modeling; Water activity; Polyphenol oxidase.

\section{Resumo}

O objetivo deste estudo foi avaliar o efeito da temperatura e do tempo de secagem sobre o conteúdo de compostos fenólicos totais e a capacidade antioxidante do bagaço de uva. Os dados experimentais das cinéticas de secagem foram ajustados a seis modelos matemáticos. O modelo de Page foi selecionado como o mais adequado para representar a secagem do bagaço de uva. A melhor preservação dos compostos fenólicos e da capacidade antioxidante foi observada a $60{ }^{\circ} \mathrm{C}$, sugerindo que as temperaturas de $40^{\circ} \mathrm{C}$ e $50{ }^{\circ} \mathrm{C}$ não foram suficientes para inativar a ação da enzima polifenoloxidase, sendo estas as responsáveis pela maior degradação desses compostos.

Palavras-chave: Capacidade antioxidante; Cinética de secagem; Modelagem matemática; Atividade de água; Polifenoloxidase.

\section{Introduction}

Grape pomace is the main by-product of the grape juice and wine industries, consisting of skin, seeds and stalks. According to FAO (2013), the world generation of winemaking waste in 2013 was approximately 3.8 million tons, resulting in a large volume that may become an environmental and economic problem.

According to Ratnasooriya and Rupasinghe (2012), about $70 \%$ of the phenolic compounds present in grapes are trapped in the grape pomace after the winemaking process, resulting in a waste rich in bioactive compounds with anti-inflammatory, anticarcinogenic, antimicrobial, antimutagenic and antioxidant potential (PÉREZ-JIMÉNEZ et al., 2008). In addition, winemaking by-products are a good source of fibers, which, compared to cereal fibers, are of better quality, due to the presence of natural antioxidants (JARA-PALACIOS et al., 2013).

Due to the high content of phenolic compounds present in grape pomace, considerable effort has been employed to optimize the extraction of these compounds and their 
use in food, pharmaceutical and cosmetic industries (MONAGAS et al., 2006; LLOBERA; CANELLAS, 2007).

However, even after extraction, a large volume of solid waste is generated, which still represents an environmental and economic problem. In this sense, drying can be suggested as an alternative to grape pomace processing, resulting in a product rich in phenolic compounds and fibers, which can be used as an ingredient in the formulation of other food products.

Convective drying using hot air is one of the most common drying techniques, being considered less expensive when compared to other dehydration methods such as freeze-drying or vacuum-drying. One of the most important process variables during convective drying is the air temperature. This variable is directly related to mass and heat transfer and, in the case of thermo-sensitive compounds, can be responsible for the preservation or degradation of these compounds.

Several studies have evaluated the drying kinetics of grape pomace using different drying methods, as well as the effect of drying on the bioactive compounds and antioxidant capacity of the final products. Vashisth et al. (2011) evaluated the use of three drying technologies (vacuum belt drying, hot air drying and freeze drying FD) as applied to muscadine pomace, and their impact on drying time, moisture content, water activity, total phenolic content and antioxidant activity of the dried pomace. Sui et al. (2014) studied the effects of infrared drying and/or convective drying on the drying kinetics of wine grape pomace, evaluating the drying characteristics, sterilizing efficacy, and the effects on the pomace polyphenol and pro-anthocyanidin contents. Tseng and Zhao (2012) evaluated the effects of conventional, vacuum oven and freeze drying on the phenolic content and antiradical scavenging activity stability of grape pomace. However, none of these works reported the degradation of bioactive compounds throughout the drying process, which could be useful to detect fluctuations in the contents of these compounds during drying, as well as to determine the time at which significant changes in this parameter begin, if any.

Thus the objective of this work was to evaluate the effect of drying temperature on the drying kinetics and bioactive compound contents and antioxidant capacity of Pinot noir grape pomace during drying.

\section{Materials and methods}

\subsection{Material}

Grape pomace was obtained from Pinot Noir grape winemaking processed by Aurora (Bento Gonçalves, RS). After manual seed separation, the pomace (skin and stems) was ground in a laboratory grinder.

\subsection{Convective drying}

For drying, a convective tray dryer with perpendicular air flow and an air velocity of $0.42 \mathrm{~m} / \mathrm{s}$ was used. The system consisted of a dryer with input and output air flow promoted by the rotation of an internal blower, with air heating promoted by incandescent lamps. The grape pomace was arranged in one tray $(0.50 \times 0.75 \mathrm{~m})$, forming a layer with approximately $0.015 \mathrm{~m}$ in height. Since the sample thickness was considerably smaller than the tray dimensions (thickness: diameter ratio $<0.1$ ), the sample behaviour was considered as a semi-infinite plate for the modelling of the experimental data (AZUARA-NIETO et al., 2003). Drying was carried out at three temperatures $\left(40^{\circ} \mathrm{C}, 50^{\circ} \mathrm{C}\right.$ and $\left.60^{\circ} \mathrm{C}\right)$. The samples were weighed on a semi-analytical balance (resolution of $0.001 \mathrm{~g}$ ) every 15 minutes during the first hour of processing, every 30 minutes for the next two hours and then every hour until the weight changes were insignificant. The drying kinetics was evaluated as the dimensionless moisture, MR (Equation 1).

$M R=\frac{X^{*}-X_{e}^{*}}{X_{i}^{*}-X_{e}^{*}}$

Where: $X^{*}$ is the average moisture content at a given time; $X^{*}$ is the equilibrium moisture content (dry basis) and $X^{*}$ is the initial moisture content (dry basis).

\subsection{Mathematical modelling}

The experimental data were adjusted using six models (Table 1). The Fick model (Equation 2) was applied considering that water migration to the surface occurred only by diffusion, that the temperature and water diffusivity were constant and that shrinkage was negligible (CRANK, 1975). Due to the long drying period (25 hours), only one term of the equation was used. The other empirical and semi-empirical models (Equations 3 to 7), commonly used to fit drying kinetics data, are also based on the Second

Table 1. Mathematical models used to fit the grape pomace convective drying data.

\begin{tabular}{|c|c|c|}
\hline Model & Equation & \\
\hline Fick & $\operatorname{Ln}(M R)=\operatorname{Ln}\left(\frac{8}{\pi^{2}}\right)-\frac{\pi^{2} D_{e f} t}{4 L^{2}}$ & (2) \\
\hline Herderson \& Pabis & $M R=\operatorname{aexp}(-k t)$ & (3) \\
\hline Page & $\mathrm{MR}=\operatorname{aexp}\left(-\mathrm{kt}^{\mathrm{n}}\right)$ & (4) \\
\hline Logarithmic (One term) & $\mathrm{MR}=\operatorname{aexp}^{(-\mathrm{kt})}+\mathrm{c}$ & (5) \\
\hline Logarithmic (Two terms) & $\mathrm{MR}=\operatorname{aexp}{ }^{(-k t)}+\operatorname{cexp}^{(-g t)}$ & (6) \\
\hline Verma & $M R=a \exp ^{(-k t)}+(1-a) \exp ^{(-g t)}$ & (7) \\
\hline
\end{tabular}

$\mathrm{MR}=$ moisture ratio $\left(\right.$ dry weight); $\mathrm{D}_{\text {f }}=$ effective diffusivity $\left(\mathrm{m}^{2} \mathrm{~s}^{-1}\right)$; $t=$ time (s); $L=$ thickness of the material to be dried; $a, c, g, k$ and $\mathrm{n}=$ model constants 
Fick's law and involve the dependence of a drying constant $(\mathrm{k})$ on the process time $(\mathrm{t})$.

The fit of the models to the experimental data was evaluated using the sum of the squared residual (SSR) and the determination coefficient $\left(R^{2}\right)$ as the statistical parameters. Modelling was carried out by non-linear regression using the SigmaPlot 8.0 software.

\subsection{Moisture content and water activity}

The moisture content was determined by drying in a vacuum oven at $65^{\circ} \mathrm{C}$ to constant weight $(\mathrm{HELRICH}$, 1990). The water activity $\left(a_{w}\right)$ was determined using an Aqualab digital hygrometer (Decagon Devices, Pullman Inc. USA) at $25^{\circ} \mathrm{C}$.

\subsection{Degradation of bioactive compounds}

In order to evaluate the effect of convective drying on the bioactive compounds of the grape pomace, the levels of total phenolic compounds and the antioxidant capacity of the samples taken at predetermined times throughout the drying process, were evaluated.

The phenolic compounds were extracted with two aqueous solutions: one with $70 \%$ acetone and the other with $50 \%$ methanol, in a ratio of grape pomace: acetone: methanol of 1:20:20. The phenolic compound content was determined by the spectrophotometric method proposed by Singleton and Rossi (1965) and modified by Georgé et al. (2005), using the Folin-Ciocalteu reagent, reading the absorbance at $760 \mathrm{~nm}$. The results were expressed as $\mathrm{g} / 100 \mathrm{~g}$ of gallic acid, on a dry weight basis.

The antioxidant capacity was measured according to the methodology described by Re et al. (1999). Absorbance readings were performed at $734 \mathrm{~nm}, 6$ minutes after the addition of the extract, and results were expressed in umol TEAC/g (Trolox Equivalent Antioxidant Capacity), in a dry basis.

\subsection{Statistical analysis}

All the experiments were carried out in triplicate and the data reported on a dry basis as the mean \pm standard deviation. The treatments were analyzed in relation to significant differences by the ANOVA and Tukey tests in order to compare the means at a significance level of $5 \%$ $(p<0.05)$ using the Statistica software, version 6.0.

\section{Results and discussion}

\subsection{Drying kinetics and mathematical modeling}

Figure 1 shows the effect of different temperatures $\left(40{ }^{\circ} \mathrm{C}, 50{ }^{\circ} \mathrm{C}\right.$ and $60{ }^{\circ} \mathrm{C}$ ) on the drying kinetics of the grape pomace. As expected, there was a decrease in moisture content (initial moisture on a dry weight basis

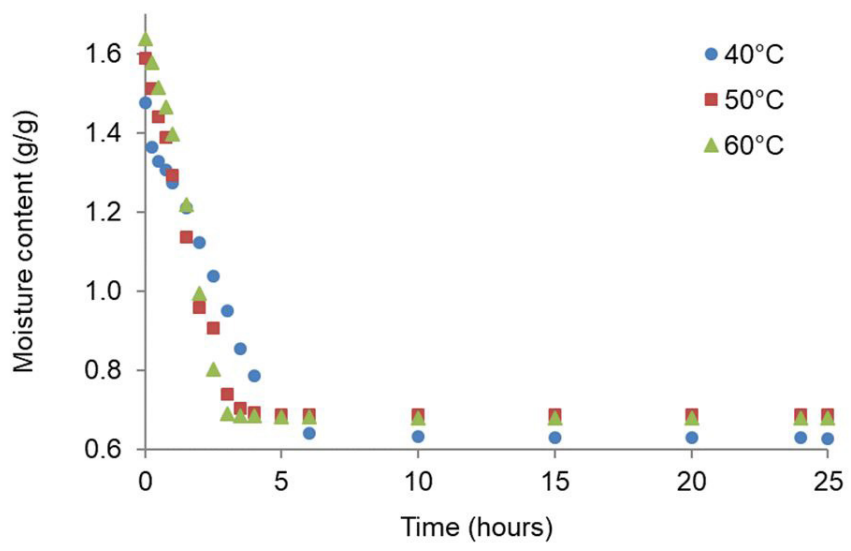

Figure 1. Moisture content (dry weight basis) during the drying of grape pomace at different temperatures.

$1.47 \pm 0.01 ; 1.59 \pm 0.01$ and $1.64 \pm 0.01$, respectively) throughout the three treatments.

The equilibrium moisture content was reached at different process times, depending on the drying temperature: samples dried at $40{ }^{\circ} \mathrm{C}, 50^{\circ} \mathrm{C}$ and $60^{\circ} \mathrm{C}$ showed no variation in the moisture content values after 360, 240 and 180 minutes, respectively. The highest temperature resulted in the shortest drying time (Figure 1), due to the higher heat and mass transfer occurring under this condition. This ehaviour was also observed during the drying of tomato slices, pears and grape pomace (DJENDOUBI et al., 2012; FERREIRA et al., 2012; SANTOS-SÁNCHEZ et al., 2012). A reduction in the drying time is associated with an increase in the drying rate, which depends on the heat transfer between the drying air and the material to be dried, resulting in better evaporation of the water from the material (AMIRI CHAYJAN et al., 2015).

All the treatments showed significant differences in relation to the final $a_{w}$ values, which were $0.601 \pm 0.01,0.270 \pm 0.01$ and $0.135 \pm 0.01$ for the pomace dried at $40^{\circ} \mathrm{C}, 50^{\circ} \mathrm{C}$ and $60^{\circ} \mathrm{C}$, respectively. The initial grape pomace $\mathrm{a}_{\mathrm{w}}$ was $0.971 \pm 0.01$, and hence reductions of $38.11 \%, 72.16 \%$ and $86.13 \%$ were observed in the processes carried out at $40^{\circ} \mathrm{C}, 50^{\circ} \mathrm{C}$ and $60{ }^{\circ} \mathrm{C}$, respectively, demonstrating that higher temperatures allowed for greater reductions in the available water present in the raw material.

The values obtained from the mathematical modelling at the different drying temperatures, as well as the parameters ( $R^{2}$ and SSR), are shown in Table 2 . The $\mathrm{R}^{2}$ value was higher than 0.95 for all settings, except for the Fick model at $60{ }^{\circ} \mathrm{C}(0.940)$, while the SSR values were lower than 0.4 for all models and treatments.

Since the Page model presented the highest $R^{2}$ values (0.986 to 0.996) and the lowest SSR values (0.012 to 0.036 ), it showed the best fit and was selected to represent the experimental data of the grape pomace drying kinetics (Figure 2). This model was also used by several authors to describe the drying processes of grape 
Table 2. Results of the mathematical modelling of the experimental data at different temperatures.

\begin{tabular}{|c|c|c|c|c|}
\hline Model & Temperature $\left({ }^{\circ} \mathbf{C}\right)$ & Model constants & $\mathbf{R}^{2}$ & SSR \\
\hline \multirow{3}{*}{ Fick } & 40 & $D_{\text {ef }}=6.341 \times 10^{-9}$ & 0.965 & 0.190 \\
\hline & 50 & $D_{e f}=1.156 \times 10^{-8}$ & 0.963 & 0.251 \\
\hline & 60 & $D_{e f}=1.143 \times 10^{-8}$ & 0.940 & 0.370 \\
\hline \multirow{3}{*}{$\begin{array}{c}\text { Henderson } \\
\text { \& Pabis }\end{array}$} & 40 & $a=1.017 ; k=0.336$ & 0.976 & 0.056 \\
\hline & 50 & $a=1.095 ; k=0.623$ & 0.975 & 0.065 \\
\hline & 60 & $a=1.131 ; k=0.629$ & 0.954 & 0.129 \\
\hline \multirow{3}{*}{ Page } & 40 & $k=0.242 ; n=1.292$ & 0.986 & 0.036 \\
\hline & 50 & $k=0.400 ; n=1.568$ & 0.996 & 0.012 \\
\hline & 60 & $k=0.296 ; n=2.020$ & 0.996 & 0.014 \\
\hline \multirow{3}{*}{$\begin{array}{c}\text { Logarithmic } \\
\text { (One term) }\end{array}$} & 40 & $a=1.040 ; k=0.320 ; c=-0.026$ & 0.977 & 0.053 \\
\hline & 50 & $a=1.120 ; k=0.585 ; c=-0.031$ & 0.976 & 0.058 \\
\hline & 60 & $a=1.164 ; k=0.587 ; c=-0.039$ & 0.955 & 0.118 \\
\hline \multirow{3}{*}{$\begin{array}{l}\text { Logarithmic } \\
\text { (Two terms) }\end{array}$} & 40 & $a=0.515 ; k=0.335 ; c=0.503 ; g=0.338$ & 0.976 & 0.056 \\
\hline & 50 & $a=0.572 ; k=0.623 ; c=0.523 ; g=0.623$ & 0.975 & 0.065 \\
\hline & 60 & $a=0.593 ; k=0.630 ; c=0.537 ; g=0.630$ & 0.954 & 0.129 \\
\hline \multirow{3}{*}{ Verma } & 40 & $a=0.662 ; k=0.329 ; g=0.329$ & 0.976 & 0.057 \\
\hline & 50 & $a=0.230 ; k=0.566 ; g=0.565$ & 0.976 & 0.084 \\
\hline & 60 & $a=0.873 ; k=0.555 ; g=0.555$ & 0.955 & 0.167 \\
\hline
\end{tabular}

$\mathrm{R}^{2}=$ coefficient of determination; $\mathrm{SSR}=$ sum of the residual squares; $D_{\mathrm{ef}}=$ effective diffusivity $\left(\mathrm{m}^{2} \mathrm{~s}^{-1}\right) ; \mathrm{a}, \mathrm{c}, \mathrm{g}, \mathrm{k}$ and $\mathrm{n}=$ models constants.

pomace, apricot and fresh pepper (TUNDE-AKINTUNDE, 2011; FERREIRA et al., 2012; IGUAL et al., 2012).

The other models were not as predictive as the Page model, with lower $\mathrm{R}^{2}$ and SSR values. One explanation for these results may be the assumption of the grape pomace layer as a homogeneous layer, which is not totally true, since there are some "spaces" between the pomace particles, which can affect the drying process, making it less homogeneous.

However, the mathematical Fick model (Equation 2), which is the basis for all the other empirical and semi-empirical models, can also be used to provide relevant information on the drying process, such as the effective diffusivity of water from the product. This information can be useful for the optimization of drying processes and construction of industrial dryers. The Fick model is related to the behaviour of the exit of water from the material. Therefore, the effective diffusivity values indicate the speed with which the water leaves the product, being higher at higher temperatures. In the present study, drying at 50 and $60{ }^{\circ} \mathrm{C}$ resulted in very similar effective diffusivities, considerably higher than that observed at $40^{\circ} \mathrm{C}$, indicating that higher temperatures favoured water diffusion inside the product. The values found for diffusivity were within the range from $10^{-12}$ to $10^{-8}$, which is common for biological materials (DOYMAZ, 2017), and were higher than those observed by Arslan and Özcan (2010) $\left(10^{-11}\right.$ to $\left.10^{-9}\right)$ for the convective air drying of food materials.

\subsection{Degradation of bioactive compounds}

The bioactive compounds were evaluated during 6 hours of drying, since after this time, no significant variations were observed in the sample moisture contents. The initial phenolic content of the grape pomace was

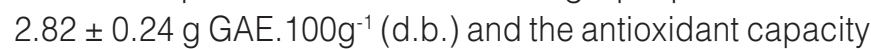
was $165.05 \pm 15.20 \mu \mathrm{mol}$ Trolox. $\mathrm{g}^{-1}$ (d.b.).

Figure 3 shows slight reductions in the phenolic compound contents and antioxidant capacities at all temperatures throughout the drying process. Some differences can also be seen between the processes carried out at different temperatures. The phenolic compound contents of samples dried at $60^{\circ} \mathrm{C}$ were slightly higher than the values observed for samples dried at the other temperatures. Regarding the antioxidant activity, the differences were more pronounced: samples dried at $60{ }^{\circ} \mathrm{C}$ showed the highest antioxidant activity, followed by samples dried at $50{ }^{\circ} \mathrm{C}$, while the grape pomace dried at $40{ }^{\circ} \mathrm{C}$ showed the lowest values. These results are contrary to some studies that reported higher degradation of bioactive compounds and antioxidant activity with increase in temperature during the drying of fruits, as well as negative effects of heat drying on the antioxidant capacity of plants (GARCIA-PEREZ et al., 2010; SUVARNAKUTA et al., 2011; DJENDOUBI et al., 2012).

According to Figure 3, in general, the process performed at $60^{\circ} \mathrm{C}$ resulted in greater phenolic compound retention and antioxidant capacity throughout the process, 

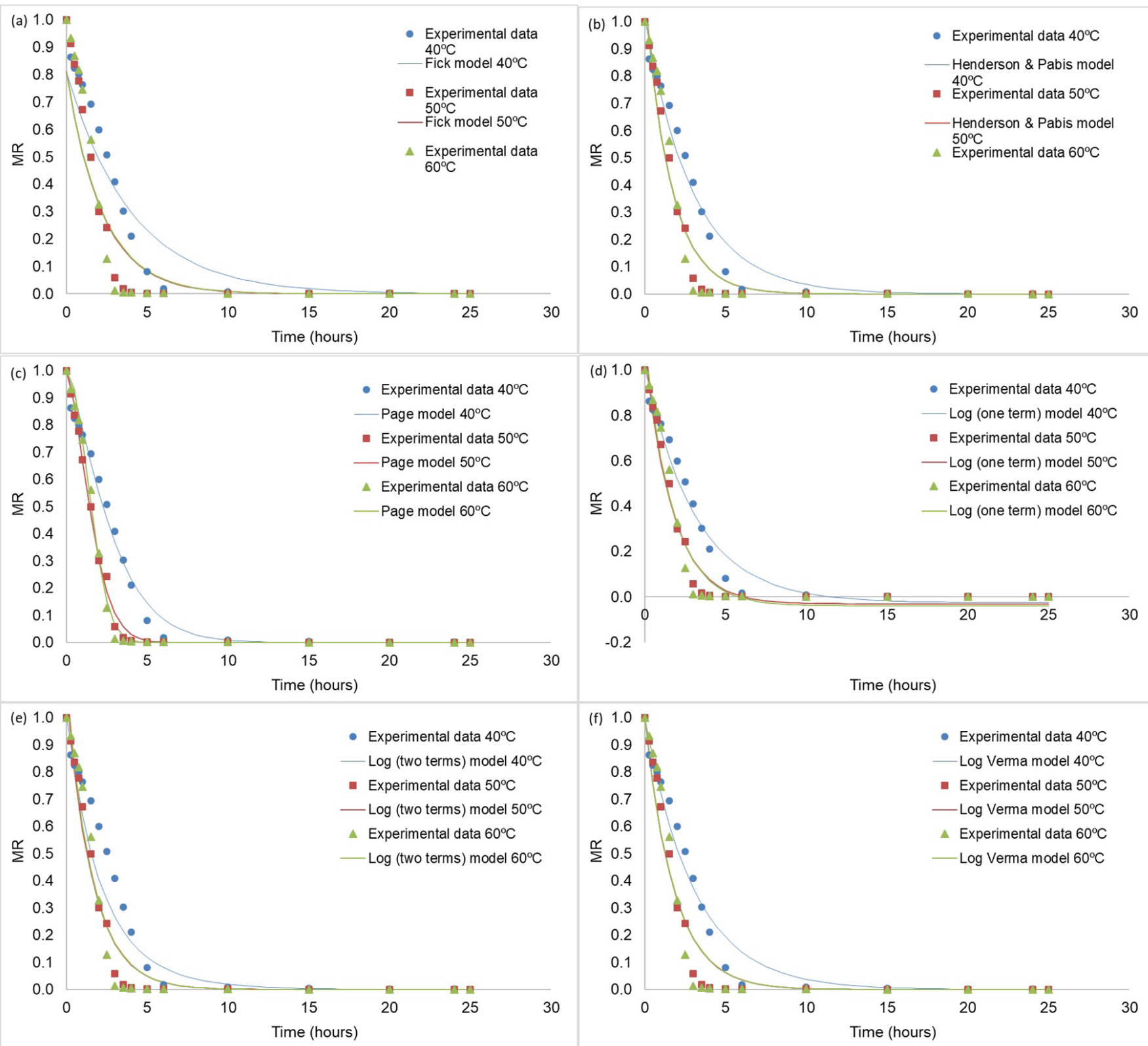

Figure 2. Experimental and estimated values during the drying of grape pomace at different temperatures: (a) Fick, (b) Henderson \& Pabis, (c) Page, (d) Logarithmic (one term), (e) Logarithmic (two terms), (f) Verma.

which is possibly related to the inhibition of the polyphenol oxidase activity in grape pomace.

Polyphenol oxidase is an enzyme that can be present in grape pomace (FORTEA et al., 2009) and is directly related to the degradation of phenolic compounds (O'DONNELL et al., 2010). This enzyme is responsible for the hydroxylation of monophenols to o-diphenols and oxidation to their corresponding quinones, therefore polymerizing to form undesirable dark coloured pigments (CHISARI et al., 2007).

According to Cheng et al. (2013), polyphenol oxidase does not show a significant loss of activity when exposed to temperatures below $55{ }^{\circ} \mathrm{C}$ for a short period of time.
However, at higher temperatures it is denatured, losing its activity in a short time with a reduction of up to $92 \%$. Terefe et al. (2015) found similar results evaluating the activation/inactivation of the polyphenol oxidase present in blueberry at temperatures of $40^{\circ} \mathrm{C}$ to $100^{\circ} \mathrm{C}$. The authors observed that the temperatures of $60^{\circ} \mathrm{C}$ to $70^{\circ} \mathrm{C}$ activated the enzyme, but that exposure of the enzyme to these temperatures for a prolonged time (more than 30 minutes) was sufficient for its inactivation.

The similar behaviour of the phenolic content and the antioxidant capacity is related to the existence of a strong correlation between these two responses, since the antioxidant capacity is a property very characteristic of these compounds (BARTOSZEK; POLAK, 2012; 
(a)
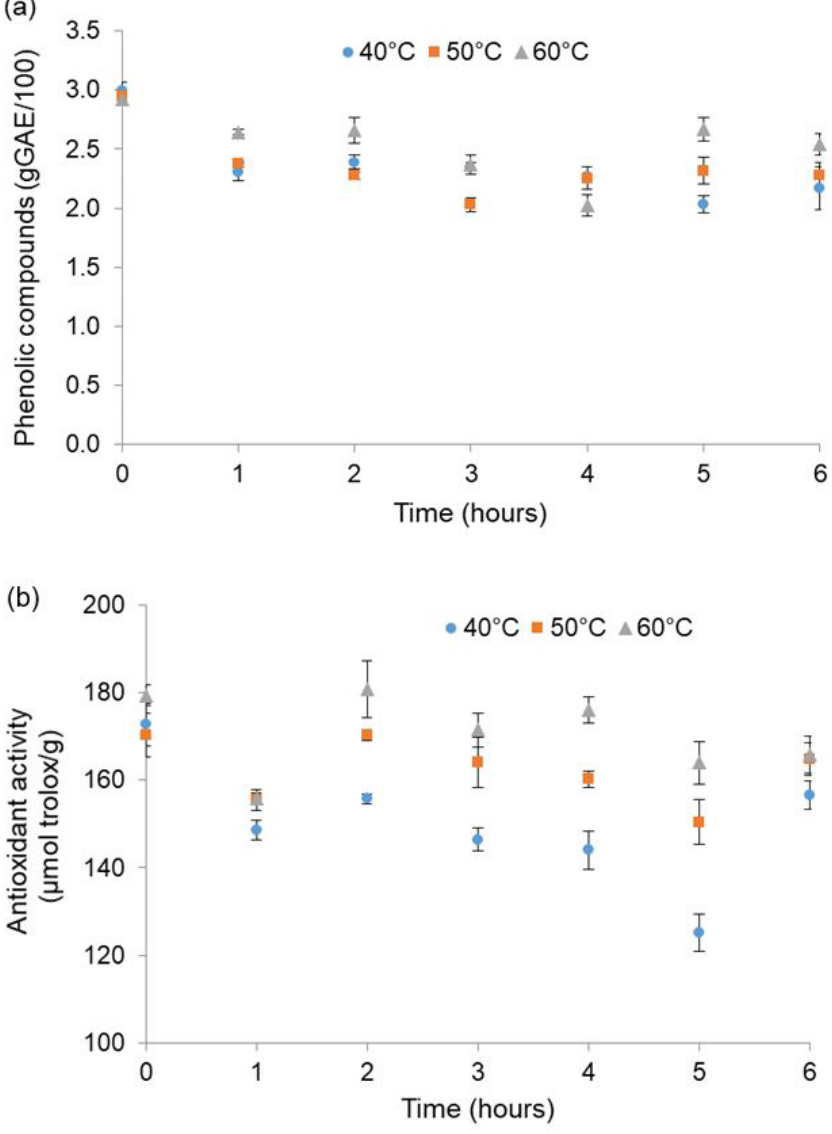

Figure 3. The effect of drying temperature on the phenolic compounds (a) and antioxidant capacity (b) of grape pomace.

NOUR et al., 2013). However, the more pronounced reduction in the antioxidant capacity rather than in the phenolic compounds may indicate that other non-phenolic compounds are responsible for the antioxidant capacity, which may have been degraded during drying.

\subsection{Influence of water activity on the degradation of phenolic compounds}

An inverse relationship was observed between water activity and the degradation of phenolic compounds in the three drying processes. The water activity of grape pomace dried at $60^{\circ} \mathrm{C}$ was lower than the values observed for those dried at $50^{\circ} \mathrm{C}$ and $40^{\circ} \mathrm{C}(0.14 \pm 0.001,0.27 \pm 0.001$ and $0.60 \pm 0.001$, respectively) (Figure 4).

This result, together with the better preservation of the phenolic compounds at this temperature, indicates that water activity may also be related to the thermal stability of enzymes that degrade phenolic compounds. Korbel et al. (2013) showed that polyphenol oxidase activity was lower at lower water activities in mango pulp, especially when the sample was subjected to heat treatment at $60^{\circ} \mathrm{C}$. Oliviero et al. (2014) reported similar results during the evaluation of myrosinase activity in dried broccoli at different temperatures. They found the

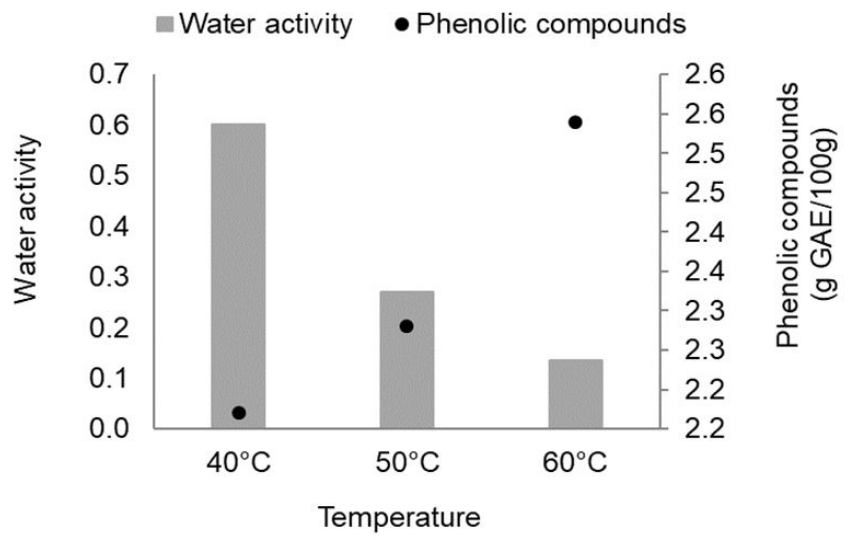

Figure 4. Water activity and phenolic compounds after 6 hours of drying at $40^{\circ} \mathrm{C}, 50^{\circ} \mathrm{C}$ and $60^{\circ} \mathrm{C}$.

highest enzymatic activity $(61 \pm 3.0)$ in samples with higher $a_{w}(0.10 \pm 0.01)$, concluding that water activity may have a great influence on enzyme stability and inactivation during thermal treatments. This theory would explain the greater retention of phenolic compounds when drying was carried out at higher temperatures.

According to Kurozawa et al. (2014) a reduction in water activity implies in a reduction in molecular diffusion through the medium, as well as in the chemical reactions occurring therein, including oxidation reactions.

Therefore, the greater retention of phenolic compounds in the process carried out at $60^{\circ} \mathrm{C}$ could be related to two factors: the lower molecular mobility associated with lower $a_{w}$ values, which makes the oxidation reactions difficult, and the loss of enzymatic activity, which can be related to the thermal effects, regarding: (a) the change in the three dimensional conformation of polyphenol oxidase and (b) the lower amount of water available for the enzyme action (GOULA; ADAMOPOULOS, 2010).

\section{Conclusions}

The experimental data of the grape pomace drying kinetics were most adequately predicted by the Page model. The drying temperature of $60^{\circ} \mathrm{C}$ resulted in lower moisture contents and better phenolic retention, consequently with higher antioxidant capacity, being considered the most suitable temperature for the convective drying of grape pomace. This result suggested a possible oxidation of bioactive compounds through the action of polyphenol oxidase in the grape pomace dried at temperatures below $60^{\circ} \mathrm{C}$, since the temperatures of $50^{\circ} \mathrm{C}$ and $40^{\circ} \mathrm{C}$ were probably not sufficient to inactivate this enzyme. In addition to the influence of temperature, a reduction in water activity may also have contributed to the reduction in enzyme activity and the occurrence of chemical reactions, thus improving the retention of phenolic compounds. These results may be useful for the optimization of the industrial drying of grape pomace, which can be used as an ingredient in 
Effect of temperature on the degradation of bioactive compounds of Pinot Noir grape pomace during drying Teles, A. S. C. et al.

food formulations, representing a source of dietary fiber and bioactive compounds with antioxidant capacity.

\section{Acknowledgements}

The authors gratefully acknowledge the financial support of the Coordination for the Improvement of Higher Level Personnel (CAPES).

\section{References}

AMIRI CHAYJAN, R.; KAVEH, M.; KHAYATI, S. Modeling drying characteristics of hawthorn fruit under microwave-convective conditions. Journal of Food Processing and Preservation, v. 39, n. 3, p. 239-253, 2015. http://dx. doi.org/10.1111/jfpp.12226.

ARSLAN, D.; ÖZCAN, M. M. Study the effect of sun, oven and microwave drying on quality of onion slices. LebensmittelWissenschaft + Technologie, v. 43, n. 7, p. 1121-1127, 2010. http://dx.doi.org/10.1016/j.Iwt.2010.02.019.

AZUARA-NIETO, E.; GUTIÉRREZ-LOPÉZ, G. F.; BERISTAIN-GUEVARA, C. I. (2003). Mass transfer description of the osmodehydration of apple slabs. In: WELTI-CHANES, J.; VÉLEZ-RUIZ, J. F.; BARBOSA-CÁNOVAS, G. V. (Ed.). Transport phenomena in food processing. Boca Raton: CRC Press, 2003. p. 95-108.

BARTOSZEK, M.; POLAK, J. An electron paramagnetic resonance study of antioxidant properties of alcoholic beverages. Food Chemistry, v. 132, n. 4, p. 2089-2093, 2012. PMid:23497862. http://dx.doi.org/10.1016/j.foodchem.2011.12.060.

CHENG, X.; ZHANG, M.; ADHIKARI, B. The inactivation kinetics of polyphenol oxidase in mushroom (Agaricus bisporus) during thermal and thermosonic treatments. Ultrasonics Sonochemistry, v. 20, n. 2, p. 674-679, 2013. PMid:23102768. http://dx.doi. org/10.1016/j.ultsonch.2012.09.012.

CHISARI, M.; BARBAGALLO, R. N.; SPAGNA, G. Characterization of polyphenol oxidase and peroxidase and influence on browning of cold stored strawberry fruit. Journal of Agricultural and Food Chemistry, v. 55, n. 9, p. 3469-3476, 2007. PMid:17407312. http://dx.doi.org/10.1021/jf063402k.

CRANK, J. The mathematics of diffusion. Cary: Oxford University Press, 1975.

DJENDOUBI, N. M.; BOUDHRIOUA, N.; KECHAOU, N.; COURTOIS, F.; BONAZZI, C. Influence of air drying temperature on kinetics, physicochemical properties, total phenolic content and ascorbic acid of pears. Food and Bioproducts Processing, v. 90, n. 3, p. 433-441, 2012. http://dx.doi.org/10.1016/j.fbp.2011.11.009.

DOYMAZ, . Drying kinetics, rehydration and colour characteristics of convective hot-air drying of carrot slices. Heat and Mass Transfer, v. 53, n. 1, p. 25-35, 2017. http://dx.doi.org/10.1007/ s00231-016-1791-8.

FERREIRA, L. F. D.; PIROZI, M. R.; RAMOS, A. M.; PEREIRA, J. A. M. Modelagem matemática da secagem em camada delgada de bagaço de uva fermentado. Pesquisa Agropecuária Brasileira, v. 47, n. 6, p. 855-862, 2012. http://dx.doi.org/10.1590/S0100204X2012000600017

FOOD AND AGRICULTURE ORGANIZATION OF THE UNITED NATIONS - FAO. Faostat agriculture data - crops production, crops processed production and food supply - grape and wine. Rome, 2013. Available at: <http://faostat.fao.org/?lang=en>. Accessed on: 9 Dec. 2014.

FORTEA, M. I.; LÓPEZ-MIRANDA, S.; SERRANO-MARTÍNEZ, A.; CARREÑO, J.; NÚÑEZ-DELICADO, E. Kinetic characterisation and thermal inactivation study of polyphenol oxidase and peroxidase from table grape (Crimson Seedless). Food Chemistry, v. 113, n. 4, p. 1008-1014, 2009. http://dx.doi.org/10.1016/j. foodchem.2008.08.053.

GARCIA-PEREZ, J. V.; GARCÍA-ALVARADO, M. A.; CARCEL, J. A.; MULET, A. Extraction kinetics modeling of antioxidants from grape stalk (Vitis vinifera var. Bobal): Influence of drying conditions. Journal of Food Engineering, v. 101, n. 1, p. 49-58, 2010. http://dx.doi.org/10.1016/j.jfoodeng.2010.06.008.

GEORGÉ, S.; BRAT, P.; ALTER, P.; AMIOT, M. J. Rapid determination of polyphenols and vitamin $C$ in plant-derived products. Journal of Agricultural and Food Chemistry, v. 53, n. 5, p. 1370-1373, 2005. PMid:15740008. http://dx.doi.org/10.1021/jf048396b.

GOULA, A. M.; ADAMOPOULOS, K. G. Kinetic models of $\beta$-carotene degradation during air drying of carrots. Drying Technology, v. 28, n. 6, p. 752-761, 2010. http://dx.doi.org/10 .1080/07373937.2010.482690.

HELRICH, K. C. Official methods of analysis of the Association of Official Analytical Chemists. Arlington: AOAC, 1990. v. 2.

IGUAL, M.; GARCÍA-MARTÍNEZ, E.; MARTÍN-ESPARZA, M. E.; MARTÍNEZ-NAVARRETE, N. Effect of processing on the drying kinetics and functional value of dried apricot. Food Research International, v. 47, n. 2, p. 284-290, 2012. http://dx.doi. org/10.1016/j.foodres.2011.07.019.

JARA-PALACIOS, M. J.; GONZÁLEZ-MANZANO, S.; ESCUDEROGILETE, M. L.; HERNANZ, D.; DUEÑAS, M.; GONZÁLEZ-PARAMÁS, A. M.; HEREDIA, F. J.; SANTOS-BUELGA, C. Study of zalema grape pomace: phenolic composition and biological effects in caenorhabditis elegans. Journal of Agricultural and Food Chemistry, v. 61, n. 21, p. 5114-5121, 2013. PMid:23639176. http://dx.doi.org/10.1021/jf400795s.

KORBEL, E.; SERVENT, A.; BILLAUD, C.; BRAT, P. Heat inactivation of polyphenol oxidase and peroxidase as a function of water activity: a case study of mango drying. Drying Technology, v. 31, n. 13, p. 1675-1680, 2013. http://dx.doi.org/10.1080/07373 937.2013.808659

KUROZAWA, L. E.; TERNG, I.; HUBINGER, M. D.; PARK, K. J. Ascorbic acid degradation of papaya during drying: effect of process conditions and glass transition phenomenon. Journal of Food Engineering, v. 123, p. 157-164, 2014. http://dx.doi. org/10.1016/j.jfoodeng.2013.08.039. 
LLOBERA, A.; CANELLAS, J. Dietary fibre content and antioxidant activity of Manto Negro red grape (Vitis vinifera): pomace and stem. Food Chemistry, v. 101, n. 2, p. 659-666, 2007. http:// dx.doi.org/10.1016/j.foodchem.2006.02.025.

MONAGAS, M.; HERNÁNDEZ-LEDESMA, B.; GÓMEZ-CORDOVÉS, C.; BARTOLOMÉ, B. Commercial dietary ingredients from Vitis vinifera L. leaves and grape skins: antioxidant and chemical characterization. Journal of Agricultural and Food Chemistry, v. 54, n. 2, p. 319-327, 2006. PMid:16417286. http://dx.doi. org/10.1021/jf051807j.

NOUR, V.; STAMPAR, F.; VEBERIC, R.; JAKOPIC, J. Anthocyanins profile, total phenolics and antioxidant activity of black currant ethanolic extracts as influenced by genotype and ethanol concentration. Food Chemistry, v. 141, n. 2, p. 961-966, 2013. PMid:23790874. http://dx.doi.org/10.1016/j.foodchem.2013.03.105.

O'DONNELL, C. P.; TIWARI, B. K.; BOURKE, P.; CULLEN, P. J. Effect of ultrasonic processing on food enzymes of industrial importance. Trends in Food Science \& Technology, v. 21, n. 7, p. 358-367, 2010. http://dx.doi.org/10.1016/j.tifs.2010.04.007.

OLIVIERO, T.; VERKERK, R.; VAN BOEKEL, M. A. J. S.; DEKKER, $M$. Effect of water content and temperature on inactivation kinetics of myrosinase in broccoli (Brassica oleracea var. italica). Food Chemistry, v. 163, p. 197-201, 2014. PMid:24912716. http:// dx.doi.org/10.1016/j.foodchem.2014.04.099.

PÉREZ-JIMÉNEZ, J.; ARRANZ, S.; TABERNERO, M.; DÍAZ-RUBIO, M. E.; SERRANO, J.; GOÑI, I.; SAURA-CALIXTO, F. Updated methodology to determine antioxidant capacity in plant foods, oils and beverages: extraction, measurement and expression of results. Food Research International, v. 41, n. 3, p. 274-285, 2008. http://dx.doi.org/10.1016/j.foodres.2007.12.004.

RATNASOORIYA, C. C.; RUPASINGHE, H. P. Extraction of phenolic compounds from grapes and their pomace using $\beta$-cyclodextrin. Food Chemistry, v. 134, n. 2, p. 625-631, 2012. PMid:23107671. http://dx.doi.org/10.1016/j.foodchem.2012.02.014.

RE, R.; PELLEGRINI, N.; PROTEGGENTE, A.; PANNALA, A.; YANG, M.; RICE-EVANS, C. Antioxidant activity applying an improved ABTS radical cation decolorization assay. Free Radical Biology
\& Medicine, v. 26, n. 9-10, p. 1231-1237, 1999. PMid:10381194. http://dx.doi.org/10.1016/S0891-5849(98)00315-3.

SANTOS-SÁNCHEZ, N. F.; VALADEZ-BLANCO, R.; GÓMEZGÓMEZ, M. S.; PÉREZ-HERRERA, A.; SALAS-CORONADO, R. Effect of rotating tray drying on antioxidant components, color and rehydration ratio of tomato saladette slices. LebensmittelWissenschaft + Technologie, v. 46, n. 1, p. 298-304, 2012. http://dx.doi.org/10.1016/j.Iwt.2011.09.015.

SINGLETON, V. L.; ROSSI, J. A. Colorimetry of total phenolics with phosphomolybdic-phosphotungstic acid reagents. American Journal of Enology and Viticulture, v. 16, n. 3, p. 144-158, 1965.

SUI, Y.; YANG, J.; YE, Q.; LI, H.; WANG, H. Infrared, convective, and sequential infrared and convective drying of wine grape pomace. Drying Technology, v. 32, n. 6, p. 686-694, 2014. http://dx.doi.org/10.1080/07373937.2013.853670.

SUVARNAKUTA, P.; CHAWEERUNGRAT, C.; DEVAHASTIN, S. Effects of drying methods on assay and antioxidant activity of xanthones in mangosteen rind. Food Chemistry, v. 125, n. 1, p. 240-247, 2011. http://dx.doi.org/10.1016/j.foodchem.2010.09.015.

TEREFE, N. S.; DELON, A.; BUCKOW, R.; VERSTEEG, C. Blueberry polyphenol oxidase: characterization and the kinetics of thermal and high pressure activation and inactivation. Food Chemistry, v. 188, p. 193-200, 2015. PMid:26041182. http:// dx.doi.org/10.1016/j.foodchem.2015.04.040.

TSENG, A.; ZHAO, Y. Effect of different drying methods and storage time on the retention of bioactive compounds and antibacterial activity of wine grape pomace (Pinot Noir and Merlot). Journal of Food Science, v. 77, n. 9, p. H192-H201, 2012. PMid:22908851. http://dx.doi.org/10.1111/j.1750-3841.2012.02840.x.

TUNDE-AKINTUNDE, T. Y. Mathematical modeling of sun and solar drying of chilli pepper. Renewable Energy, v. 36, n. 8, p. 2139-2145, 2011. http://dx.doi.org/10.1016/j.renene.2011.01.017.

VASHISTH, T.; SINGH, R. K.; PEGG, R. B. Effects of drying on the phenolics content and antioxidant activity of muscadine pomace. Lebensmittel-Wissenschaft + Technologie, v. 44, n. 7, p. 1649-1657, 2011. http://dx.doi.org/10.1016/j.Iwt.2011.02.011. 